\title{
Effect of an Educational Training Program for Nurses about Infection Control Precautions in Their Practice in the Pediatric Critical Care
}

\author{
Samya Abde EL-Badiea EL-Shafey, Amal Mohammed El-Dakhakhny, \\ Bataa Mahmoud Mohammed \\ Pediatric Nursing Department, Faculty of Nursing, Zagazig University, Egypt.
}

Corresponding Author

Samya Abde ELBadiea EL-Shafey

Mobile:

$+201067055933$

E mail: samya_elshafey@yaho o.com

Key words:

Infection Control

Precautions, Nurses, educational program
Background and study aim: Infection control is essentially a clinical service directly related to improving and maintaining the quality of patient care. The aim of the present study was to identify the impact of an educational training program for nurses about infection control precautions in their practice in the pediatric critical care units.

Materials and methods: A quasiexperimental study was conducted on sample of 70 nurses. The present study was conducted at pediatric Intensive care unit \& Hemodialysis unit at pediatric hospital as well as, operation rooms at pediatric surgery department in Zagazig University Hospital. Two tools were used; first a questionnaire sheet to assess nurses' knowledge and the second tool was an observational checklist used to assess nurses' practice. In addition, an

\section{INTRODUCTION}

Infections represent a significant hazard in all health care setting. Therefore, infection control is everyone business, and it is important that all members of the staff observe good infection control practice. Infection is a major safety and health hazard. Some infections are minor and cause short illness. While; others are serious and can cause death [1].

Infection is a condition in which the body is invaded by pathogens, which then increase in number, causing injurious effects with its symptoms usually present. Infection doesn't always cause a disease [2].

A nosocomial infection (NI) is a problem of both developed and developing countries. A nosocomial infection is educational program about infection control to improve nurses' knowledge and practice related to infection control precaution.

Results: The results showed that nurses had unsatisfactory knowledge about infection control before implementation of educational program. Nurses' knowledge and practice had been improved significantly after implementation of educational program either immediately or 2 months later.

Conclusion: It can be concluded that educational program had improved nurses' practice about infection control. Based on the results of the present study, In-service, training program for nurses about infection control precautions should be done. In addition, the development of infection control guidelines is essential, to be followed and available for all nurses. one that is acquired by patients during hospitalization or by health care workers through their work in the hospital $[3,4]$. It becomes a significant problem in most hospitals and may affect $2 \%$ to $8 \%$ of all hospitalized patient [5]. Hospital-Acquired infection (HAI) is a major health problem in all societies. According to the WHO, 7.1 million cases of HAI occur every year. One out of every 20 people suffers from hospital infection. This leads to 99,000 cases of death every year and imposes an estimated cost of $\$ 32$ million to society [6].

Pediatric nurses are at risk of occupational exposure to infection associated with clinical, diagnostic and therapeutic procedures [7]. Therefore, nurses' compliance with standard precautions of infection control guide- 
lines and preventive measures is crucial to prevent the transmission of infectious pathogens [8]. The pediatric patients are faced with increased risks of nosocomial infections and so, lifethreatening conditions because of the lack immunity to many pathogens, use of invasive procedures and devices and frequent exposure to broad spectrum antibiotic agents $[\mathbf{9 , 1 0}]$

Preterm infants that hospitalized in neonatal units are more susceptible to infection and mortality due to their immature immune systems $[\mathbf{1 1 , 1 2 ]}$. Therefore, prevention and treatment of nosocomial infections in neonatal units is very important.

Standard precautions are the systems of infection control precautions which must be applied to all children at all times regardless of diagnosis or infectious status, in any setting in which healthcare is delivered [13]. Implementation of standard precautions constitutes the primary strategy for the prevention of healthcare-associated transmission of infectious agents among children and healthcare personnel. Standard precautions combine the major features of universal precautions (UP) and body substance isolation (BSI) and are based on the principle that all blood, body fluids, secretions, excretions except sweat, skin, and mucous membranes may contain transmissible infectious agents [14].

Elements of standard precautions include proper hand hygiene and use of gloves, gown, mask, eye protection, face shield, and safe injection practices. Equipments or items used in the patient environment that may be contaminated with infectious body fluids are also handled in a manner to prevent transmission of infection, including cleaning, disinfecting, and sterilizing before use on another patient. Application of Standard Precautions is determined by the type of care interaction anticipated [15]. The goal of universal precautions is to interrupt the transmission of germs by decreasing the chance that will come into contact with them [16].

Infection control program started focusing mainly on the ministry of health and population hospitals such as university hospitals and private hospitals. Moreover, a critical component of the infection control program in Egypt is the promotion of occupational safety and health [17].

Nurses must be aware of the problems of nosocomial infections and its effects on patients' morbidity, increased hospital stay; costs; as well as, the legal aspect concerning them. Also, the nurse must have knowledge about the types of infection, the common pathogens and how it can be transmitted, the factors that predispose a patient to nosocomial infection; how to recognize those at risk, and the prevention and control measures necessary to decrease the incidence of nosocomial infection. Nursing staff has been responsible for development of infection control program in intensive care unit and commitment is needed for continuing education, continuing re-evaluation of policies and procedures and empowerment of all team members to achieve the program goals $[\mathbf{1 8 , 1 9 ]}$.

Aim of the Study: The aim of this study is to identify the impact of an educational training program for nurses about infection control precautions in their practice in the pediatric critical care units.

\section{SUBJECTS AND METHODS}

\section{Research design:}

A quasi- experimental design was used in the study.

\section{Setting}

The study was conducted at the following setting

1- Intensive care unit (ICU) at pediatric hospital at Zagazig University Children Hospital

2- Hemodialysis unit (HD) at pediatric hospital at Zagazig University Children Hospital

3- Operation room (OR) at pediatric surgery Department at Zagazig University Hospital.

\section{Subjects:}

The subjects of this study was comprised of all nurses (70) working and providing direct nursing care for children in the above mentioned settings regardless of their age, qualification or years of experience.

\section{- Tools of data Collection:}

The data collection tools for the current study were composed of two tools, a questionnaire sheet and an observational checklist.

\section{1- Structured Interview Questionnaire Sheet:}

It was guided by Ebrahem [20] and modified by the researcher to assess nurses' knowledge about infection control precautions in their practice in the pediatric critical care units.

The questionnaire consisted of Personnel characteristics of nurses including: age, sex, level of education, years of experience, training 
program, and attendance of infection control precautions training programs.

\section{2- Infection Control Precaution Chicklist :}

It was guided by Abd El-Samea [13] \& Ebrahem [20] and modified by the researcher to evaluate nurses' practice about infection control precautions provided to children through different procedures.

\section{It consists of:}

Infection control precautions regarding hand washing, gloving, wearing mask, gown, child's preparation, care of equipments, garbage and needle disposal, handling linens and nurses' practice in maintenance of critical care unit environment. It was composed of two main dimensions, general and specific control measures.

\section{Scoring system:}

Each correct answer was scored 1 point and zero for wrong one. The total score was 190 marks for practice. The total score for practice about infection control precaution was classified as satisfactory $\geq 60 \%$, unsatisfactory $<60 \%$

\section{Validity and reliability:}

In the present study the overall reliability of the structure interview questionnaire (Cronbach's Alpha test (0.863), acceptable).The structured observational checklist (Cronbach's Alpha test was (0.785), acceptable). Content validity was achieved by a panel of three experts (two professors of pediatric nursing, and one professors of pediatric medicine) who revised the tools for clarity, relevance, comprehensiveness, understanding and ease for implementation. Modifications were applied according to their opinions.

\section{3-The Educational Program}

Educational Program was developed to improve nurses' practice about infection control.

\section{General objective of the program}

The general objective of the program is to improve nurses' practice about infection control precautions.

\section{Specific objective of the program}

At the end of this educational training program, nurses will be able to :

1- Apply infection control precautions regarding hand washing, personnel protective equipment, children's preparation, care of equipment; rubbish and needle disposal, handling linens and nurses practice in maintenance of the care units.
2- Apply methods of rubbish disposal and linen handling.

\section{The Educational Program was developed} through four phases as following:

\section{(I) Assessment phase:}

The educational program was partially constructed for the assessment of nurse's practice. The assessment was performed before implementation of educational program by interviewing each nurse individually to assess practice (pre test) by using tool $1 \&$ tool 2 after explaining the aim of the study and their approval to participate in the study. This phase started prior to the planning of the protocol and aimed identifying setting of the sample that had been involved; its facilities and resources. After identifying the nurses, they were met in ICU, OR, Dialysis unit. Nurses fill out the questionnaire sheet in the morning and afternoon shifts. The time taken for filling out the questionnaire sheet varied between 15-20 minutes. Also, nurses' practices were observed.

\section{(II) Planning phase}

Based on the results obtained from interview sheet and observational checklist (from pilot study and assessment phase) as well as reviewing the related literature the educational program was developed by the researcher. Detected needs, requirements and deficiencies were translated into aim and objectives of the educational program. The contents of the educational health program were selected on the basis of identified needs.

Teaching methods were selected to suit teaching in small groups in the form of lectures, group discussion, demonstrations and re-demonstrations. Teaching materials were prepared as lectures by laptop, group discussion, demonstration, colored posters and real application on patients, Power Point, a handbook of the designed program contents illustrated by pictures by the researcher that covered theoretical and practical information.

\section{(III) Implementation phase:}

The educational program of this study was implemented through 7 sessions in which nurses were divided into small groups to facilitate the learning process. The length of each session differed according to the content and nurses responses. It was ranged from 30-45minutes.

The first session about Hospital infection, second and third sessions about Infection control precautions, fourth session about Caring of the 
Children in the dialysis unit, five sessions about caring of the children with artificial breathing, sex session about caring of the wound and seven session about care of C.V.P and cannula. Each session started with summary of the previous session and the objectives of the new one taking were explained in Arabic language and simple English terms that suit level of nurse's education. Motivation and reinforcement during session were used in order to enhance nurses learning.

\section{(IV) Evaluation phase:}

- In this phase every nurse of the studied nurse sample were interviewed individually immediately after implementation of educational health program to assess their practice (post test) by using tool 1 and tool 2 .

- Also after 2 months later the nurses of the studied sample reassessed for their practice (follow up) using tool 1 and tool2.

- This study was carried out for 6 months during the period from November 2015 to April 2016.

\section{Pilot study:}

A pilot study was carried out on $10 \%$ of the sample who met the study criteria. Nurses included in the pilot study were selected randomly, and later they were excluded from the main sample of research work to assure stability of the answers. The purpose of the pilot study was to test the clarity and applicability of the study tool and to determine the time needed to complete the questionnaire sheet for each participant.

\section{Field work:}

After identifying the nurses who fulfilled the criteria of the study, they were requested to participate in the study. The purpose of the study was explained briefly to nurses who were willing to participate. They were met by the researcher at the end of each shift at their available time (after providing nursing activities of the unit) from 3 $\mathrm{pm}$ and $7 \mathrm{pm}$. The researcher was available 4 days weekly. As regards the nurse's practices, they were observed in the previously mentioned settings during their actual work in different shifts

\section{Administrative Design:}

To carry out the study in the selected setting, an approval was obtained from the director of Pediatric Hospitals and Surgery Hospitals.

\section{Statistical design:}

The data were analyzed by using SPSS (Statistical Package for Social Sciences) software program version 15 , which was applied to frequency tables. Statistical significance and association were assessed using chi-square test and $\mathrm{r}$ (correlation) to correlate between the studied variables. $\mathrm{P}$ values which were less than $0.05 \& 0,001$ were considered as statistically significance and highly significant respectively. Number and percentage, mean and standard deviation were used. The given graphs were constructed using Microsoft Excel soft ware.

\section{RESULTS}

It was found that $32.9 \%$ of the studied nurses were at the age group 25 to less than 30 years, with mean age of $30.10 \pm 18.30$ years. Also $42.9 \%$ of the studied nurses had nursing school diploma, while, $24.3 \%$ of the nurses had nursing bachelor degree. As regard years of experience in nursing field, it was reported that $44.3 \%$ had less than 10 years of experience with mean of $13.01 \pm 7.02$ years. Also, $42.9 \%$ of the studied subjects attended training program about infection control (Table 1).

Statistical significant improvement throughout the program phases regarding Hand washing, wearing the Mask, Wearing sterile gown, Personal hygiene, Equipments, Handling needles, Soiled Linens and Specimen Collection (Table 2).

Statistical significant improvement throughout the program phases regarding Treatment area and Healthy behavior (Table 3).

Statistical significant improvement throughout the program phases regarding Prevention and control of respiratory infection, endo-tracheal suction and suction machine, wound infection, medications and fluids, urinary tract infection and intravascular device (Table 4).

There was statistical significant improvement throughout the program phases regarding ICP before, during and after procedure of hemodialysis (Table 5).

Impact of Educational Program on Nurse's Practice score was portrayed in figure (1).

It reveals that only $1.4 \%$ of the studied nurses had satisfactory practice score before implementation of educational program. this percentage increased to $97.1 \%$ after implementation of educational 
program, and decreased to $87.1 \%$ in the follow up phase ;the difference was statistically significant (McNemar test was $164.32 * *)$.
There was no statistical significance relation between Personnel characteristics of the studied nurses and total mean practice score throughout the program phases (Table 6).

Table (1): Characteristic of the Studied Nurses (N=70).

\begin{tabular}{|c|c|c|}
\hline Personnel characteristics & No & $\%$ \\
\hline \multicolumn{3}{|l|}{ Age in years } \\
\hline Less than 20 years & 11 & 15.7 \\
\hline $20-$ & 10 & 14.3 \\
\hline $25-$ & 23 & 32.9 \\
\hline $31-$ & 13 & 18.6 \\
\hline $33-40$ & 13 & 18.6 \\
\hline Mean \pm SD & \multicolumn{2}{|c|}{$30.10 \pm 18.30$} \\
\hline \multicolumn{3}{|l|}{ Educational qualification } \\
\hline Nursing bachelor & 17 & 24.3 \\
\hline Nursing Institute Diplome & 23 & 32.9 \\
\hline Nursing school Diplome & 30 & 42.9 \\
\hline \multicolumn{3}{|l|}{ Years of experience in nursing } \\
\hline $1-$ & 31 & 44.3 \\
\hline $11-$ & 23 & 32.9 \\
\hline $21-30$ & 16 & 22.9 \\
\hline Mean \pm SD & \multicolumn{2}{|c|}{$13.01 \pm 7.02$} \\
\hline \multicolumn{3}{|c|}{ Years of experience at neonatal critical care } \\
\hline $1-$ & 57 & 81.4 \\
\hline $11-$ & 6 & 8.6 \\
\hline \multirow[t]{2}{*}{$20-30$} & 7 & 10.0 \\
\hline & \multicolumn{2}{|c|}{$7.83 \pm 6.48$} \\
\hline \multicolumn{3}{|l|}{ Job description } \\
\hline Supervisor & 20 & 28.6 \\
\hline Head nurse & 13 & 18.6 \\
\hline Nurse & 37 & 52.9 \\
\hline \multicolumn{3}{|c|}{ Previous training regarding infection control } \\
\hline No & 40 & 57.1 \\
\hline Yes & 30 & 42.9 \\
\hline \multicolumn{3}{|l|}{ Feed back } \\
\hline Good & & 26.7 \\
\hline Average & & 43.3 \\
\hline Poor & & 30.0 \\
\hline
\end{tabular}


Table (2): Total Nurses Practice Scores regarding General infection control precautions at different phases of the program $(\mathrm{N}=70)$

\begin{tabular}{|c|c|c|c|c|c|c|c|c|c|c|c|c|c|c|}
\hline \multirow{3}{*}{$\begin{array}{l}\text { General infection } \\
\text { control measures }\end{array}$} & \multicolumn{4}{|c|}{ Pre-intervention } & \multicolumn{4}{|c|}{ Post-intervention } & \multicolumn{4}{|c|}{ Follow up } & \multirow{3}{*}{$\begin{array}{c}\text { Mc } \\
\text { Nemar test }\end{array}$} & \multirow{3}{*}{ p-value } \\
\hline & \multicolumn{2}{|c|}{ Unsatisfactory } & \multicolumn{2}{|c|}{ Satisfactory } & \multicolumn{2}{|c|}{ Unsatisfactory } & \multicolumn{2}{|c|}{ Satisfactory } & \multicolumn{2}{|c|}{ Unsatisfactory } & \multicolumn{2}{|c|}{ Satisfactory } & & \\
\hline & No & $\%$ & No & $\%$ & No & $\%$ & No & $\%$ & No & $\%$ & No & $\%$ & & \\
\hline $\begin{array}{l}\text { hand Washing and } \\
\text { overshoes }\end{array}$ & 43 & $61.4 \%$ & 27 & $38.6 \%$ & 19 & $27.1 \%$ & 51 & $72.9 \%$ & 22 & $31.4 \%$ & 48 & $68.6 \%$ & 20.35 & $<0.001^{* *}$ \\
\hline $\begin{array}{l}\text { Wearing the Mask \& } \\
\text { goggles }\end{array}$ & 48 & $68.6 \%$ & 22 & $31.4 \%$ & 20 & $28.6 \%$ & 50 & $71.4 \%$ & 23 & $32.9 \%$ & 47 & $67.1 \%$ & 27.49 & $<0.001^{* *}$ \\
\hline Wearing sterile gown & 50 & $71.4 \%$ & 20 & $28.6 \%$ & 23 & $32.9 \%$ & 47 & $67.1 \%$ & 27 & $38.6 \%$ & 43 & $61.4 \%$ & 23.42 & $<0.001^{* *}$ \\
\hline $\begin{array}{ll}\text { Personal } & \text { hygiene, } \\
\text { Equipments } & \end{array}$ & 47 & $67.1 \%$ & 23 & $32.9 \%$ & 23 & $32.9 \%$ & 47 & $67.1 \%$ & 26 & $37.1 \%$ & 44 & $62.9 \%$ & 19.86 & $<0.001^{* *}$ \\
\hline $\begin{array}{l}\text { Handling needles \& } \\
\text { other sharp instruments }\end{array}$ & 51 & $72.9 \%$ & 19 & $27.1 \%$ & 15 & $21.4 \%$ & 55 & $78.6 \%$ & 19 & $27.1 \%$ & 51 & $72.9 \%$ & 46.17 & $<0.001^{* *}$ \\
\hline Chemical disinfection & 49 & $70.0 \%$ & 21 & $30.0 \%$ & 12 & $17.1 \%$ & 58 & $82.9 \%$ & 16 & $22.9 \%$ & 54 & $77.1 \%$ & 50.73 & $<0.001^{* *}$ \\
\hline Soiled Linens & 55 & $78.6 \%$ & 15 & $21.4 \%$ & 14 & $20.0 \%$ & 56 & $80.0 \%$ & 18 & $25.7 \%$ & 52 & $74.3 \%$ & 60.16 & $<0.001^{* * *}$ \\
\hline Notification \&Isolation & 51 & $72.9 \%$ & 19 & $27.1 \%$ & 13 & $18.6 \%$ & 57 & $81.4 \%$ & 16 & $22.9 \%$ & 54 & $77.1 \%$ & 54.07 & $<0.001^{* *}$ \\
\hline Specimen Collection & 52 & $74.3 \%$ & 18 & $25.7 \%$ & 14 & $20.0 \%$ & 56 & $80.0 \%$ & 17 & $24.3 \%$ & 53 & $75.7 \%$ & 53.35 & $<0.001^{* *}$ \\
\hline
\end{tabular}

Table (3): Total Nurses practice scores regarding Maintenance of Critical Care Unit's Environment at different phases of the program ( $\mathrm{N}=70$ )

\begin{tabular}{|c|c|c|c|c|c|c|c|c|c|c|c|c|c|c|}
\hline \multirow{3}{*}{$\begin{array}{c}\text { Maintenance of critical care } \\
\text { unit's environment }\end{array}$} & \multicolumn{4}{|c|}{ Pre-intervention } & \multicolumn{4}{|c|}{ Post-intervention } & \multicolumn{4}{|c|}{ Follow up } & \multirow{3}{*}{$\begin{array}{c}\text { Mc } \\
\text { Nemar } \\
\text { test }\end{array}$} & \multirow{3}{*}{ p-value } \\
\hline & \multicolumn{2}{|c|}{ Unsatisfactory } & \multicolumn{2}{|c|}{ Satisfactory } & \multicolumn{2}{|c|}{ Unsatisfactory } & \multicolumn{2}{|c|}{ Satisfactory } & \multicolumn{2}{|c|}{ Unsatisfactory } & \multicolumn{2}{|c|}{ Satisfactory } & & \\
\hline & $\mathrm{N}_{0}$ & $\%$ & $\mathrm{~N}_{0}$ & $\%$ & $\mathrm{~N}_{0}$ & $\%$ & $\mathrm{~N}_{0}$ & $\%$ & $\mathrm{~N}_{0}$ & $\%$ & $\mathrm{~N}_{0}$ & $\%$ & & \\
\hline Treatment area & 44 & $62.9 \%$ & 26 & $37.1 \%$ & 18 & $25.7 \%$ & 52 & $74.3 \%$ & 21 & $30.0 \%$ & 49 & $70.0 \%$ & 24.18 & $<0.001^{* *}$ \\
\hline Healthy behavior & 46 & $65.7 \%$ & 24 & $34.3 \%$ & 19 & $27.1 \%$ & 51 & $72.9 \%$ & 23 & $32.9 \%$ & 47 & $67.1 \%$ & 24.92 & $<0.001^{* *}$ \\
\hline
\end{tabular}

Significant at $\mathrm{P}<0.001^{* *}$

Table (4): Total Nurses practice scores regarding Specific infection control precautions at different phases of the program ( $N=70)$

\begin{tabular}{|c|c|c|c|c|c|c|c|c|c|c|c|c|c|c|}
\hline \multirow{3}{*}{$\begin{array}{l}\text { Specific infection control } \\
\text { measures }\end{array}$} & \multicolumn{4}{|c|}{ Pre-intervention } & \multicolumn{4}{|c|}{ Post-intervention } & \multicolumn{4}{|c|}{ Follow up } & \multirow{3}{*}{$\begin{array}{c}\text { Mc } \\
\text { Nemar } \\
\text { test }\end{array}$} & \multirow{3}{*}{ p-value } \\
\hline & \multicolumn{2}{|c|}{ Unsatisfactor } & \multicolumn{2}{|c|}{ Satisfactory } & \multicolumn{2}{|c|}{ Unsatisfactor } & \multicolumn{2}{|c|}{ Satisfactory } & \multicolumn{2}{|c|}{ Unsatisfactory } & \multicolumn{2}{|c|}{ Satisfactory } & & \\
\hline & No & $\%$ & No & $\%$ & No & $\%$ & No & $\%$ & No & $\%$ & No & $\%$ & & \\
\hline $\begin{array}{l}\text { Regarding Prevention and } \\
\text { control of respiratory infection }\end{array}$ & 57 & $81.4 \%$ & 13 & $18.6 \%$ & 11 & $15.7 \%$ & 59 & $84.3 \%$ & 15 & $21.4 \%$ & 55 & $78.6 \%$ & 77.61 & $<0,001^{* *}$ \\
\hline $\begin{array}{l}\text { Endo tracheal suction and } \\
\text { suction machine }\end{array}$ & 52 & $74.3 \%$ & 18 & $25.7 \%$ & 13 & $18.6 \%$ & 57 & $81.4 \%$ & 17 & $24.3 \%$ & 53 & $75.7 \%$ & 55.26 & $<0.001^{* *}$ \\
\hline $\begin{array}{l}\text { Prevention and control of } \\
\text { wound infection }\end{array}$ & 44 & $62.9 \%$ & 26 & $37.1 \%$ & 18 & $25.7 \%$ & 52 & $74.3 \%$ & 21 & $30.0 \%$ & 49 & $70.0 \%$ & 24.18 & $<0.001^{* *}$ \\
\hline Chest tubes & 50 & $71.4 \%$ & 20 & $28.6 \%$ & 19 & $27.1 \%$ & 51 & $72.9 \%$ & 20 & $28.6 \%$ & 50 & $71.4 \%$ & 36.31 & $<0.001 * *$ \\
\hline Medications and fluids & 50 & $71.4 \%$ & 20 & $28.6 \%$ & 13 & $18.6 \%$ & 57 & $81.4 \%$ & 16 & $22.9 \%$ & 54 & $77.1 \%$ & 51.41 & $<0.001^{* *}$ \\
\hline $\begin{array}{l}\text { Prevention and control of } \\
\text { urinary tract infection }\end{array}$ & 55 & 78.6 & 15 & 21.4 & 16 & 22.9 & 54 & $77.1 \%$ & 20 & $28.6 \%$ & 50 & $71.4 \%$ & 53.56 & $<0.001^{* *}$ \\
\hline $\begin{array}{l}\text { Prevention and control of } \\
\text { intravascular device }\end{array}$ & 51 & 72.9 & 19 & 27.1 & 14 & 20.0 & 56 & 80.0 & 18 & 25.7 & 52 & 74.3 & 49.28 & $<0.001^{* *}$ \\
\hline
\end{tabular}

Significant at $\mathrm{P}<0.001$ **

Table (5): Total Nurses practice scores regarding ICP during hemodialysis at different study phases. $(\mathrm{N}=70)$.

\begin{tabular}{|c|c|c|c|c|c|c|c|c|c|c|c|c|c|c|}
\hline \multirow{3}{*}{ ICP during hemodialysis } & \multicolumn{4}{|c|}{ Pre-intervention } & \multicolumn{4}{|c|}{ Post-intervention } & \multicolumn{4}{|c|}{ Follow up } & \multirow{3}{*}{$\begin{array}{c}\text { Mc } \\
\text { Nemar } \\
\text { test }\end{array}$} & \multirow{3}{*}{$\mathrm{p}$-value } \\
\hline & \multicolumn{2}{|c|}{ Unsatisfactory } & \multicolumn{2}{|c|}{ Satisfactory } & \multicolumn{2}{|c|}{ Unsatisfactory } & \multicolumn{2}{|c|}{ Satisfactory } & \multicolumn{2}{|c|}{ Unsatisfactory } & \multicolumn{2}{|c|}{ Satisfactory } & & \\
\hline & No & $\%$ & No & $\%$ & No & $\%$ & No & $\%$ & No & $\%$ & No & $\%$ & & \\
\hline $\begin{array}{l}\text { ICP before procedure of } \\
\text { hemodialysis }\end{array}$ & 52 & $74.3 \%$ & 18 & $25.7 \%$ & 15 & $21.4 \%$ & 55 & $78.6 \%$ & 19 & $27.1 \%$ & 51 & $72.9 \%$ & 48.71 & $<0.001^{* *}$ \\
\hline $\begin{array}{l}\text { ICP during procedure of } \\
\text { hemodialysis }\end{array}$ & 44 & $62.9 \%$ & 26 & $37.1 \%$ & 20 & $28.6 \%$ & 50 & $71.4 \%$ & 24 & $34.3 \%$ & 46 & $65.7 \%$ & 19.40 & $<0.001^{* *}$ \\
\hline $\begin{array}{l}\text { ICP after procedure of } \\
\text { hemodialysis }\end{array}$ & 45 & $64.3 \%$ & 25 & $35.7 \%$ & 22 & $31.4 \%$ & 48 & $68.6 \%$ & 24 & $34.3 \%$ & 46 & $65.7 \%$ & 18.88 & $<0.001 * *$ \\
\hline
\end{tabular}

Significance at $\mathrm{P}<0.001^{\text {*** }}$ 


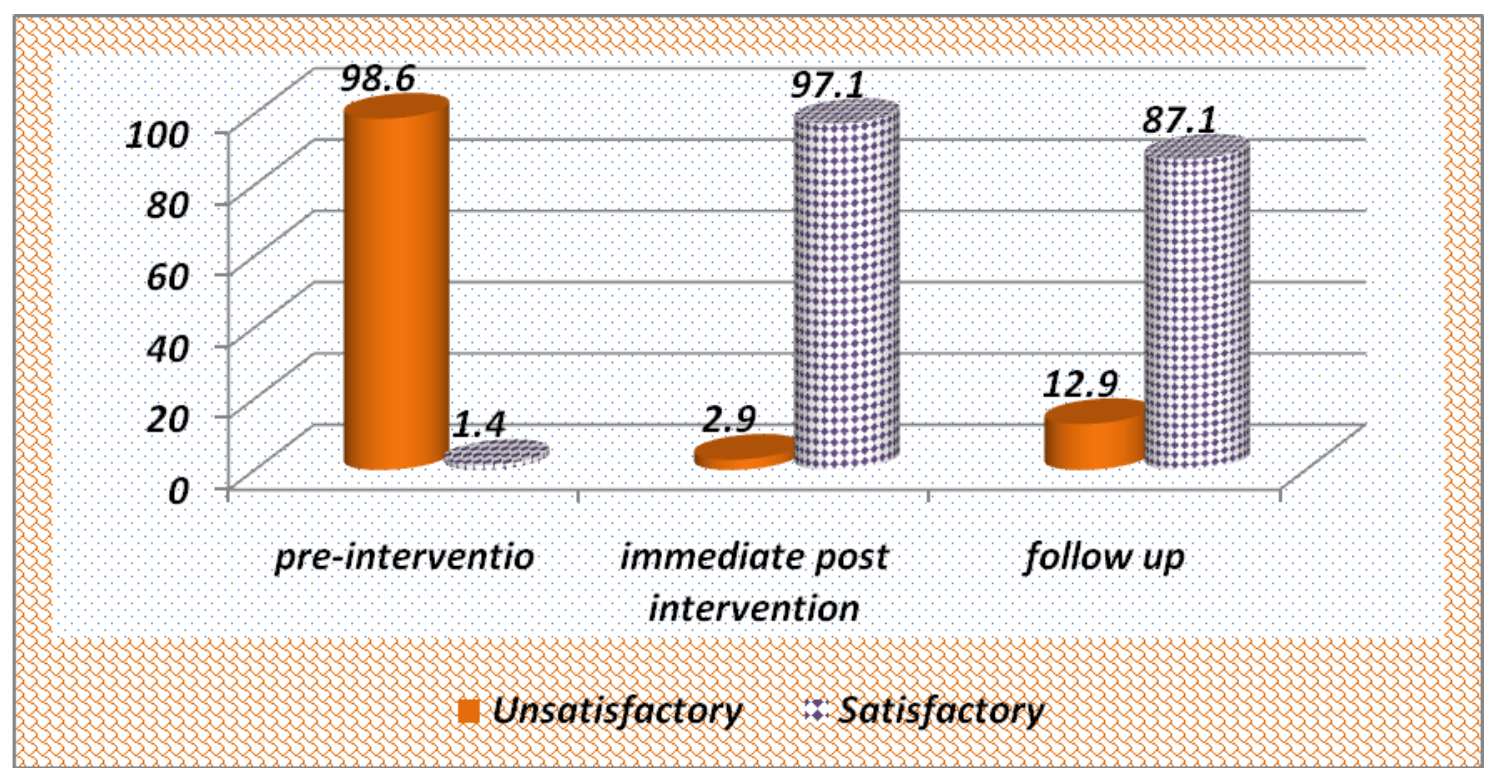

Figure (1): Total Nurses practice scores at different phases of the program $(\mathrm{N}=70)$

Table (6): Relationship between Nurses characteristics and Total Mean Practice score through the program ( $\mathrm{N}=70)$

\begin{tabular}{|c|c|c|c|c|c|c|c|c|c|}
\hline \multirow{2}{*}{ Personnel characteristics } & \multicolumn{3}{|c|}{ Pre-intervention } & \multicolumn{3}{|c|}{ Post-intervention } & \multicolumn{3}{|c|}{ Follow up } \\
\hline & Mean \pm SD & F test & p-value & Mean \pm SD & F test & p-value & Mean \pm SD & F test & p-value \\
\hline Age in years & & \multirow[t]{6}{*}{0.879} & \multirow[t]{6}{*}{$>0.05$} & & \multirow[t]{6}{*}{2.04} & \multirow[t]{6}{*}{$>0.05$} & & \multirow[t]{6}{*}{1.30} & \multirow[t]{6}{*}{$>0.05$} \\
\hline Less than 20 years & $133.9091 \pm 30.98856$ & & & $320.7273 \pm 26.56724$ & & & $292.4545 \pm 23.59815$ & & \\
\hline $20-$ & $129.2000 \pm 35.23193$ & & & $319.4000 \pm 21.50039$ & & & $290.6000 \pm 29.78143$ & & \\
\hline $25-$ & $119.9565 \pm 35.85257$ & & & $293.6522 \pm 33.87492$ & & & $272.3913 \pm 29.75313$ & & \\
\hline $31-$ & $135.7692 \pm 29.05786$ & & & $302.6154 \pm 35.65001$ & & & $281.4615 \pm 28.74200$ & & \\
\hline $33-40$ & $117.3077 \pm 31.68434$ & & & $307.6923 \pm 30.17555$ & & & $285.3077 \pm 27.92664$ & & \\
\hline Educational qualification & & \multirow{4}{*}{0.763} & \multirow[t]{4}{*}{$>0.05$} & & \multirow[t]{4}{*}{0.197} & \multirow[t]{4}{*}{$>0.05$} & & \multirow[t]{4}{*}{0.193} & \multirow[t]{4}{*}{$>0.05$} \\
\hline Baculare of nursing & $117.8235 \pm 32.31144$ & & & $304.4706 \pm 35.57056$ & & & $277.0000 \pm 28.05352$ & & \\
\hline Technical nursing education & $130.7391 \pm 36,02678$ & & & $315,3043 \pm 27,62482$ & & & $291.0870 \pm 28.96693$ & & \\
\hline Secondary nursing education & $126.8000 \pm 31.15855$ & & & $299.4000 \pm 32.24112$ & & & $278.4000 \pm 28.00566$ & & \\
\hline Years of experience in nursing & & \multirow[t]{4}{*}{2.75} & \multirow[t]{4}{*}{$>0.05$} & & \multirow[t]{4}{*}{0.559} & \multirow[t]{4}{*}{$>0.05$} & & \multirow[t]{4}{*}{0.365} & \multirow[t]{4}{*}{$>0.05$} \\
\hline $1-$ & $126.2903 \pm 32.85746$ & & & $310.3871 \pm 26.13513$ & & & $284.6774 \pm 25.36190$ & & \\
\hline 11- & $135.6957 \pm 31.80971$ & & & $301.7391 \pm 35.60544$ & & & $285.1739 \pm 28.65413$ & & \\
\hline $21-$ & $111.1250 \pm 31.33874$ & & & $303.0000 \pm 37.39519$ & & & $273.2500 \pm 34.12819$ & & \\
\hline $\begin{array}{l}\text { Years of experience at neonatal } \\
\text { critical care }\end{array}$ & & \multirow[t]{4}{*}{0.274} & \multirow[t]{4}{*}{$>0.05$} & & \multirow[t]{4}{*}{0.411} & \multirow[t]{4}{*}{$>0.05$} & & \multirow[t]{4}{*}{0.553} & \multirow[t]{4}{*}{$>0.05$} \\
\hline $1-$ & $124.5088 \pm 33.70943$ & & & $304.2105 \pm 30.86997$ & & & $281.2456 \pm 26.97901$ & & \\
\hline $11-$ & $132.6667 \pm 23.54287$ & & & $311.6667 \pm 45.98116$ & & & $294.0000 \pm 39.20714$ & & \\
\hline $20-30$ & $131.5714 \pm 36.67359$ & & & $314.2857 \pm 30.88535$ & & & $280.1429 \pm 34.50328$ & & \\
\hline Job description & $114.4000 \pm 32.05325$ & 7.22 & $>0.05$ & $304.0000 \pm 33.22650$ & 0.096 & $>0.05$ & & 0.206 & $>0.05$ \\
\hline Previous training regarding(IC & & \multirow[t]{3}{*}{0.489} & \multirow[t]{3}{*}{$>0.05$} & & \multirow[t]{3}{*}{0.196} & \multirow[t]{3}{*}{$>0.05$} & & 0.440 & $>0.05$ \\
\hline No & $127.9697 \pm 33.51537$ & & & $306.6667 \pm 36.67311$ & & & $283.8485 \pm 31.71368$ & & \\
\hline Yes & $124.0811 \pm 32.86198$ & & & $305.1351 \pm 27.60652$ & & & $280.7838 \pm 25.90488$ & & \\
\hline
\end{tabular}

Statistically Significant at $\mathrm{P}<0.005$ 


\section{DISCUSSION}

The incidence of infection in critical care units (ICUs) is one of the highest in hospitals; however, facilities to prevent infection are often inadequate in these important areas [21]. Furthermore, multiple invasive procedures such as IV cannula, urinary catheter, nasogastric tube and enema are performed in intensive care units, although great care is taken to control morbidity and prevent mortality, this invasive environment places intensive care units, children and staff at a great risk of infection [22].

Concerning age of studied nurses, the results of the present study showed that one third of the studied nurses were at the age group 25 to- $<30$ years, and less than half of them less than 10 years of experience. There was no statistical significant difference between nurses practice about infection control and neither their age nor their years of experience. This may be due to that most of the studied nurses were nursing school diploma. These finding are consist ant with Saleh [23] and Ahmed [24]. Also Gad Allah [4] found that, no statistical significance relation between level of nurses practice and their age and years of experience.

Regarding educational qualification of the studied nurses, the current study revealed that less than half of the studied nurses having nursing school diploma. There was no statistical significant relation between nurses' practice about infection control and their level of knowledge. This result may be due to the relation between practice and level of education could be different. Higher education level did not necessary lead to increased practice unless there is updating of knowledge through continuing nursing education. Also, this finding is due to the nature of the nursing work as baccalaurean nurses work as supervisor or in administrative work and nurses with diploma work directly with children. This result was in the same line with results of Saleh [23] and Gad Allah [4] who found that there was no statistical significant relationship between nurse's level of practice and level of education. Also, this result was in the same line with results of Sadawy [25] who found that more than half of studied nurses had nursing diploma and there is no significant relationship between nurses practice and their educational qualification.

The present study indicated that less than half of the studied nurses had adequate practice score in relation to hand washing steps before program, this finding was increased in practice scores after program implementation and in follow up to include most of them. This result was in harmony with Ismail [26] who found that all nurses wash their hands before any procedure. On the other hand, this finding was not in agreement with Saleh [23] who found that despite, the wide spread of knowledge about importance of hand washing among most nurses who had satisfactory level of knowledge regarding hand washing; it was not practiced by most of them. Also, this result disagree with Abd El-Aziz [17] who reported that very low percentage of them had adequate practice related to hand washing. This result may be due to implementation of educational program and using of standards infection control protocols or due to good habits beside effective supervision.

In the present study, more than two third of the observed nurses had adequate practice score in relation to wearing mask steps after implementation of program and in follow up phase. These results was in agreement with Abd El-lateef [27] who found that an improvement was observed in nurses practice scores pre-post program implementation regarding wearing protective clothes. The result of the present study may be due to good supervision, or providing equipment and facilities to protect them from infection at the areas they are working.

The current study revealed that majority of the studied nurses had inadequate practice before program related to handling of soiled linens; this percentage improved to include most of them after the program implementation and in follow up phase. This finding agrees with Abd El-Aziz [17] who found that less than half of studied nurses had adequate practice related to handling of soiled linens. Also, Gad Allah [4] reported that, the dirty linen should be separated using a color coding system on the ward. This might be due to lack of close supervision, or neglection of nurses, therefore, linens were collected in bags and sent to laundry.

The current study showed that most of the studied nurses had proper practice related to the specimens' items. These finding were satisfactory in post program and in follow up phase. These results agrees with Soliman [28] as, he found that all of the specimens' collection steps were satisfactory pre and post the program. The finding of the present study could be due to the importance of investigation and analysis of specimens for discovering of early infection. Or, it might be due to hospital policy.

As regards to prevention and control of wound infection, the current study showed that the studied 
nurses had adequate practice scores related to items of pre operation wound care, post operative care after program implementation and in follow up phase. This result could be due to their good behavior related to dressing procedures from school training and work overload assigned to nurses. This finding agrees with Soliman [28] who found that majority of nurses had adequate practice related to items (suitable time for wound opening, dressing of clean wounds before aseptic wounds).

As regarding nurses practice related to prevention and control intravascular device related infection, it was observed that the studied nurses had inadequate practice scores related to almost of items before program. After the program, most of the studied nurses had adequate practice score. This result may be due to nurses didn't receive program about care of intravascular device. This result agree with Abd El-Aziz [17] who found none of the studied nurses had adequate practice score regarding to vein puncture and changing dressing of central venous catheter.

Concerning the nurses' practices in this study regarding the standard precautions of infection control, the present study showed that, significant improvement immediately after the intervention and at follow-up related to hand washing, gloving, gowning and masking. The researchers attributed this that, although, these practices done routinely in their units but, there are some factors may hinder its' competency such as, work overload, unawareness with the correct steps, or inadequate time to make the procedure correctly such as hand washing. So, these results could reflect the nurses' need to refresh and update their skills. Moreover, the clinical practices are continually growing and changing and, specific clinical practices may evolve as a result of new evidence. This result is congruent with Abd-Alla [29] who found that, inadequate practices related to standard precautions of infection control could be due to lack of nurses' awareness with the importance of infection control and safe health practice. Similarly, Abolwafa et al. [30] stated that, an improvement among the majority of nurses' knowledge and practice was found after implementation of the training program about infection control.

Ismail [26] reported that assessment and documentation by the emergency department staff was found to be generally poor and this may reflect a lack of experience. This finding go in line with the results of the present study where, most of the studied nurses had unsatisfactory performance regarding infection control before implementation of educational program. This poor practice may be attributed to lack of facilities, guidance, reinforcement and inadequate training educational program about infection control.

\section{CONCLUSION}

It can be concluded that the educational health program to nurses had a profound effect on improving their knowledge and practice about infection control precautions as there was statistical difference throughout the three phases of the study.

\section{Ethical Considerations:}

Nurses' oral consents were obtained before starting data collection. The aim of the study was explained to all participates. They were assured about confidentiality and anonymity of the study. They were informed about their right to refuse or withdraw from the study at any time without giving a reason.

\section{Funding:}

None.

\section{Conflicts of interest:}

There are no conflicts of interest.

\section{REFERENCES}

1. Abo Ella TH. Adequacy of Nursing Care facilities effect on Nurses Infection Control behavior during antenatal and postnatal care in maternity hospital. El-Mania University Hospital, 2008.

2. William J. Hospital acquired infection: principles and prevention. $3^{\text {rd }}$ ed., Oxford: Boston. 2012, pp:13-22.

3. Martelli ME. Giving A medicated enema: In nurses Clinical Guide to Medication Administration. Spring house. http: hralth. Enotes.com/nursing. enclopedia/enema-adminstration.5/7/2017, 2007.

4. Gad Allah HM. Assessment of nurse's performance in premature units at Zagazig University Hospitals. Published Master Thesis, faculty of Nursing. Zagazig University, 2007, pp:45-77.

5. Mc Cann JS. Critical care Nursing made Incredibly Easy. Lippicott Williams \& Wilkins, New York, 2008, Pp: 1-2.

6. Cardo D, Dennehy PH, Halverson P, Fishman N, Kohn M, Murphy CL. Moving toward elimination of healthcare-associated infections: a call to action. Infection Control. 2010. 31:1101-1105. http://dx.doi.org/10.1016/j.ajic.2010.09.001. [PubMed]

El-Shafey et al., Afro-Egypt J Infect Endem Dis 2019; 9(1):20-30

https://aeji.journals.ekb.eg/

http://mis.zu.edu.eg/ajied/home.aspx 
7. Vandijck DI, Cleemput J, Hellings and Vogelaers D. Infection Prevention and Control Strategies in the era of limited resources and Quality improvement: A perspective paper. Australian Critical Care, 2013, 26: 154-7.

8. Ching YS. The effectiveness of Educational Programs to Improve The Knowledge and Compliance of health care workers towards standard precautions. M.S. Thesis, University of Hong Kong, 2007.

9. Garland JS. Strategies to Prevent Ventilator Associated Pneumonia in Neonates. Clinics in Perinatology, 2010. 37: 629-643.

10. Richard MD, Polin D, Susan MD, Michael S and Brady T. Strategies for prevention of health careassociated infections in the NICU, Pediatrics, 2012, 129: e1085-e1093.

11. Verklan MT, and Walden M. Core curriculum for neonatal intensive care nursing. $4^{\text {th }}$ ed. Texas: $W B$ Saunders Co; 2010.

12. Ward D. The role of Education in the Prevention and Control of Infection: a review of the literature. Nurse Education Today, 2011. 31: 917.I

13. Abd El Samea RS. Universal Precaution Followed By Pediatric Nurses to prevent infection among children undergoing hemodialysis. published Master Thesis, Faculty of Nursing, Zagazig University. 2013, p.28-29.

14. Sigel JD, Rhinehart E, and Jackson M. Guideline for Isolation Precautions: Preventing Transmission of Infectious Agents in Health Care Settings. Available at http: //www. cdc.gov/ncidod/ dhaqp/ pdf/ isolation.pdf. Accessed on 20/8/2016, 2007.

15. Centers for Disease Control and Prevention (CDC). Sterilization or disinfection of medical devices. Retrieved from http://www.cdc.gov, 2011.

16. El Awady SM. Complience Universal Precaution Nurses and Laboratory technician in Mansoura International specialized Hospital. Published Master thesis. Faculty of Nursing. Zagazig University, 2008, p, 34.

17. Abd El-Aziz EM. Educational program for monitoring of nosocomial bacterial infection control measures at intensive care unit. Zagazig University Hospital. Published Doctora thesis. Faculty of Nursing Zagaig University, 2008, P: 48- 90 .

18. Steven MP. Watching them wash description of a hand hygiene observation program. Infect control Hosp Epidemiol. Feb; 2010, 31(2)198-9.
19. Amoran OE and Onwube OO. Infection control and practice of standard precautions among healthcare workers in Northern Nigeria. Journal of Global Infectious Diseases, 2013, 5: 156-163.

20. Ebrahim GG. Effect of Inservice Educational Program for nurses about infection Control Precautions in their practice in hemodialysis Units. published Doctora Thesis. Faculty of Nursing. Mansoura University, 2013, P.50-53.

21. Moustafa MS. Nurses Complience Standards of Nursing Care in Performing invasive procedures at Zagazig University Hospitals. Published Master Thesis, Faculty of Nursing, Zagazig University, 2008, pp: 32-40, 140-145.

22. Centers for Disease Control and Prevention. National Healthcare Safety Network. DeviceAssociated Module. Protocol and Instructions: Central Line- Associated Bloodstream Infection Event. http://www.cdc.gov/nhsn/psc_da.html. Accessed on March 2016, 2012.

23. Saleh MS. Nurses Compliance to Standards of Nursing Care in Performing Invasive Procedures at Zagazig University Hospitals. published Master thesis. Faculty of Nursing. Zagazig University, 2008, pp:100-105.

24. Ahmed SA. Study of Nurse's Performance Regarding Infection Control for Patients with Central Venous Catheter. published Master thesis, Faculty of Nursing. Zagazig University, 2007, p:25.

25. Sadawy S. Clinical Practice Guidelines for prevention of Central line infection in Zagazig University. Published Master thesis, Faculty of Nursing. Zagaig University, 2013, pp:34-45.

26. Ismail M. Evaluate nursing intervention offered to premature neonates at neonatal intensive care unit in Zagazig University. Published Master Thesis, Faculty of Nursing, Zagazig University, 2010, p.30.

27. Abd El-Lateef AM. Designing, Implementing and Evaluating Educational Program for prevention of Infection in Burn Unit, Unpublished Doctoral Thesis. Faculty of Nursing. Zagazig University, 2003, pp:69-70, 72-76.

28. Soliman MW. Implementing and Evaluating Training program on infection control for nurses at intensive care units. Published Doctorate Thesis, Faculty of Nursing, Zagazig University, 2010, p.88.

29. Abd-alla A. Impact of Health Education on infection control measures in an operating theater. Published Doctoral Thesis, Tanta University, 2008. 
30. Abolwafa NF, Ouda FZ Mohammed MR and Masoed, ES. Developing educational program for nurses' related to infection control of invasive procedures in neonatal units at EL-Minia university and general hospitals. Journal of American Science, 2013, 9: 286-293.

El-Shafey et al., Afro-Egypt J Infect Endem Dis 2019; 9(1):20-30

https://aeji.journals.ekb.eg/

http://mis.zu.edu.eg/ajied/home.aspx 